\title{
WESTERN EUROPEAN EXAMPLE OF DEFENSE DEVELOPMENT
}

\author{
Beatrix FREGAN, ${ }^{1}$ Zoltán RAJNAI ${ }^{2}$ \\ ${ }^{1}$ National University of Public Service, Budapest, Hungary, fregan.beatrix@uni-nke.hu \\ ${ }^{2}$ Óbuda University, Budapest, Hungary, rajnai.zoltan@bgk.uni-obuda.hu
}

\begin{abstract}
It is particularly important for the French political leadership to maintain French independence, to develop military defense capabilities and to maintain a balance between budgetary constraints. The publication presents a European way of continuously modernizing the French army and modernizing its technical tools. France has one of the strongest and most powerful armed forces characterized by adapting NATO-based applications and procedures.
\end{abstract}

Keywords: force, weapon upgrading, reconnaissance, military industry.

\section{The fundamentals of defense policy}

The fundamentals of France's defense policy and the use of the armed forces are defined in the national defense strategy while the country's security and defense policy are described in the strategic documents that are in the defense White Books and the military budget planning laws.

The White Book that was compiled in 2013 designates general directions for defense, strategy and security regarding the development of the French armed forces until 2025, the Law for Military Planning specified the budgetary means necessary for their implementation for the 20152019 period.

Among the main elements of the White Book there are the identification of the risks and threats that come as a result of the changes in national security environment; also the adaptations of the geo-strategic priorities to these changes. A domain that received special attention in the geo-political perspective is the increased number of crisis hubs in Africa and the Middle East that especially preoccupies the French political elite but there is a special emphasis on the renewed Russian power politics along the borders of the EU. [1]

In military strategy prevention as a basic function of strategic operations is built upon the ap- plication of traditional forces with the exertion of the capacity for regional crisis solving. The main purpose of military strategy is to prevent situations that could potentially carry indirect or direct threats, to ensure the use of armed forces and the keeping of conflicts and crisis situations at a minimal level.

Strategy reinterprets the notion of intelligence as a sum of all strategic level actions that contribute to France's capacity to autonomously recognize situations. This activity consists human or technical intelligence at a national level or in cooperation in order to gather information either about certain states or about international terrorist organizations.

This system of intelligence allows for recognizing events that are to be expected and the preparation and execution of any necessary operations.

Intelligence has always been a basis for military action. It has a special importance nowadays too in the process of preparing both defensive and offensive operations, since knowing the strength and the situation of the enemy is the key of the success for any action by the armed forces.

Due to the multi-faceted character of the threats the nature of intelligence has also become more diverse encompassing non-military areas too. Therefore the French conception of national de- 
fense pays special attention to recognition and prevention.

Further elements of reactive capability: the ability to react immediately; gradual mobilization of pre-arranged or very mobile forces; supporting the forces; the deployment of land units, airborne forces and navy for prevention purposes and if necessary, the execution of special operations.

\section{The main documents of defense de- velopment}

In 2013 the White Book of defense and national security gave a special attention to the role of human intelligence, and the capacity to analyze and interpret a situation.

The terrorist attacks suffered by France in the last few years call for even more attention to these aspects, therefore in 2016 the number of employees working in this domain was increased by 1000. [2]

The 2014-2019 Law for Military Planning significantly increased the intelligence services' rights to access data and it also gave more control to the Parliament. Thus these services can access evidences of central authorities, of the police, of criminal investigations and of phone networks. Already in 2008 a position of national intelligence coordinator was established under the direct authority of the President of the Republic, the job of which was to coordinate the contacts between the different organizations involved in investigations and intelligence.

Sharing data from investigations is the key to the success of military operations outside the borders, which also largely depends on the intention to cooperate with the armed forces of neighboring countries.

\subsection{French defense industry and modern- ization}

The strengthening of the military industry significantly contributes to the realization of autonomous strategic capacities and it also vitalizes the economy through the use of about four thousand companies and suppliers. Defense industry projects are coordinated, announced and executed by the Chief Council for Armaments that is a part of the Ministry for Defense.

According to the 2014-2019 Law for Military Planning the French defense industry can count during these six years on state funds in the amount of approximately 17 billion Euros. This kind of modernization of military techniques concerns all branches and components of the armed forces, in the same time though financial restraints, the appearance of new players on the market and the competition seriously influenced the number of commissions.

Therefore the interest of the French decision-makers turned more and more towards projects conducted in international civil cooperation. Throughout the modernization of the defense sector defense-related researches and technologies became the priority, these are concentrated on the following domains:

-further development of the components of nuclear deterrence;

- use of unmanned aircraft, renewal of rocket systems, a preference for a British-French cooperation framework in the field of developing the military aircraft of the future;

- network solutions for modular aquatic and subaquatic military systems, innovative architectures

-improvement of military vehicles and of the protection of their personnel, development of new ammunition technologies;

-increasing the efficiency of cyber-defense capabilities;

- possibilities to develop systems of communication, of radio-navigation and of satellite analysis;

- digitalizing the geo-physical environment.

Decision makers in the domain of defense often emphasize that the military industry represents a significant percentage of the economy. In 2012 it generated an income of 15 billion Euros.

Although there areabout four thousand small and middle sized companies working in the military industry, the activity of this branch of industry is concentrated mainly in a few big companies. In 2013 five companies obtained two thirds of all commissions in arms acquisitions: Airbus Group, DCNS, Thales, Safran and Dassault. [3]

Funds directed towards developing defense research in 2015 were as high as 3.6 billion Euros which was $2.1 \%$ more than the amount spent in 2014. Of this, 739 million Euros were spent on applied technical research.

The financial effort was made necessary by serious military and strategic challenges. It's a social expectation to secure the operational superiority of the military against any potential enemy by developing and implementing modern weapons systems. 
Table 1. Significant contributors of military industry in France

\begin{tabular}{|c|c|c|c|c|c|c|}
\hline $\begin{array}{l}\text { Military } \\
\text { industry } \\
\text { group (Mil- } \\
\text { lion Euros) }\end{array}$ & $\begin{array}{l}\text { Total income } \\
\text { in } 2014\end{array}$ & $\begin{array}{l}\text { Percentage } \\
\text { of the mili- } \\
\text { tary indus- } \\
\text { try from } \\
\text { total income }\end{array}$ & $\begin{array}{l}\text { Total num- } \\
\text { ber }\end{array}$ & $\begin{array}{c}\text { Increase of } \\
\text { total income } \\
2011-2014 \\
(\%)\end{array}$ & $\begin{array}{c}\text { Increase of } \\
\text { income in } \\
\text { the military } \\
\text { industry } \\
2011-2014 \\
\text { (\%) }\end{array}$ & Domains of activity \\
\hline $\begin{array}{l}\text { AIRBUS } \\
\text { GROUP }\end{array}$ & 60713 & $18 \%$ & 138622 & $24 \%$ & $-7 \%$ & $\begin{array}{l}\text { Military and civilian } \\
\text { helicopters, drones, } \\
\text { satellites, cyber-de- } \\
\text { fense }\end{array}$ \\
\hline $\begin{array}{l}\text { DASSAULT } \\
\text { AVIATION }\end{array}$ & 3680 & $27 \%$ & 11745 & $11 \%$ & $11 \%$ & $\begin{array}{l}\text { Military and unman- } \\
\text { ned aircraft, satellite } \\
\text { and pyro-technical } \\
\text { products }\end{array}$ \\
\hline DCNS & 3066 & $99 \%$ & 14024 & $17 \%$ & $17 \%$ & $\begin{array}{l}\text { Warships, submari- } \\
\text { nes, weapons systems, } \\
\text { operating systems, } \\
\text { marine drone integ- } \\
\text { ration, nuclear energy }\end{array}$ \\
\hline MBDA & 2400 & $100 \%$ & 10000 & $-20 \%$ & $-20 \%$ & $\begin{array}{l}\text { Air-to-air rockets, re- } \\
\text { mote controlled wea- } \\
\text { pons }\end{array}$ \\
\hline NEXTER & 1048 & $100 \%$ & 3324 & $23 \%$ & $23 \%$ & $\begin{array}{l}\text { Weapons systems, am- } \\
\text { munitions, air-ground } \\
\text { robots, night vision } \\
\text { systems for armored } \\
\text { devices }\end{array}$ \\
\hline $\begin{array}{l}\text { RENAULT } \\
\text { TRUCKS } \\
\text { DEFENSE }\end{array}$ & 384 & $100 \%$ & 1200 & $52 \%$ & $52 \%$ & $\begin{array}{l}\text { Military vehicles, tur- } \\
\text { ret weapons systems }\end{array}$ \\
\hline SAFRAN & 15044 & $20 \%$ & 68945 & $29 \%$ & $29 \%$ & $\begin{array}{l}\text { Warship and rocket } \\
\text { propulsion, naviga- } \\
\text { tion, electronics, cri- } \\
\text { tical software, protec- } \\
\text { ted drone systems }\end{array}$ \\
\hline THALES & 12974 & $52 \%$ & 60781 & $0 \%$ & $-11 \%$ & $\begin{array}{l}\text { Warships, communi- } \\
\text { cations systems, wea- } \\
\text { pons systems, simu- } \\
\text { lation systems, space } \\
\text { devices }\end{array}$ \\
\hline
\end{tabular}

The French consider the long term autonomy of the French military industry in regard to its industrial capacities to be of primary importance. The military industry is on a continuous lookout for synergies between military and civilian do- mains not only at the level of the big companies but also by the involvment of small and middle-sized businesses in the activities of military research and development.

\section{Conclusion}

For the French leadership maintaining the capacity to act autonomously and keeping a balance between developing military defense capacities and the budgetary constraints is of primary importance. Through the continuous modernization of its armed forces and its technical equipment France has one of the strongest and most efficient military forces in all of Europe, one that is characterized by the adaptation of NATO-based implementations and procedures. 
Table 2. Large International military industry companies 2014 (M\$ US)

\begin{tabular}{|c|c|c|}
\hline Company & Country & Sales of armament \\
\hline Lockheed Martin & USA & 37470 \\
\hline Boeing & USA & 28300 \\
\hline BAE Systems & UK & 25730 \\
\hline Raytheon & USA & 21370 \\
\hline Northrop Grumman & USA & 19660 \\
\hline General Dynamics & USA & 18600 \\
\hline Airbus Group & Europe & 14490 \\
\hline $\begin{array}{l}\text { United Technologies } \\
\text { Corp. }\end{array}$ & USA & 13020 \\
\hline Finmeccanica & Italy & 10540 \\
\hline L-3 Communications & USA & 9810 \\
\hline Almaz-Antey & Russia & 8840 \\
\hline Thales & France & 8600 \\
\hline $\begin{array}{l}\text { BAE Systems Inc. } \\
\text { (BAE Systems UK) }\end{array}$ & USA & 8360 \\
\hline $\begin{array}{l}\text { Huntington Ingalls } \\
\text { Industries }\end{array}$ & USA & 6680 \\
\hline United Aircraft Corp. & Russia & 6110 \\
\hline $\begin{array}{l}\text { United Shipbuilding } \\
\text { Corp. }\end{array}$ & Russia & 5980 \\
\hline Rolls-Royce & UK & 5430 \\
\hline SAFRAN & France & 5130 \\
\hline $\begin{array}{l}\text { Honeywell } \\
\text { International }\end{array}$ & USA & 4750 \\
\hline Textron & USA & 4700 \\
\hline
\end{tabular}

\section{References}

[1] Les Chiffres Clés de la Défense édition 2016. Ministère de la Défense, Paris, Annuaire statistique de la défense, Édition 2016, Paris.

[2] Ministère des Armées. Livre blanc. Défense et sécurité nationale 2013.

http://www.defense.gouv.fr/content/download/206186/2286591/Livre-blanc-sur-la-Defenseet-la-Securite-nationale\%202013.pdf
[3] Ministère des Armées. LOI no 2015-917 du 28 juillet 2015 actualisant la programmation militaire pour les années 2015 à 2019 et portant diverses dispositions concernant la défense.

www.defense.gouv.fr/portail/enjeux2/politique-de-defense/la-loi-de-programmation-militaire-lpm-2014-2019/actualisation-de-la-loi-de-programmation-militaire-lpm-2014-2019/lpm 